\title{
Kutatásokkal az emberkereskedelem ellen
}

\section{Researches in the field of counter-trafficking}

\author{
Berkes Márton \\ emberkereskedelem elleni szakreferens, \\ Belügyminisztérium, \\ Emberkereskedelem Elleni és Horizontális Ügyek Osztálya \\ marton.berkes@bm.gov.hu
}

\begin{abstract}
Absztrakt
Cél: Az elmúlt két év során több előremutató kutatás is zajlott az emberkereskedelem elleni küzdelem területén. Az esszé bemutatja a kutatások hatókörét, a főbb eredményeket és megállapításokat, ezáltal is ösztönözve a szakmában dolgozókat és a szélesebb közönséget az elkészült kiadványok tanulmányozására. Módszertan: A fenti cél érdekében három könyvismertetőt adunk közre.

Megállapítások: A kutatásoknak köszönhetően megbízható, tudományos eredményeken alapuló szakmai háttér segíti az emberkereskedelem elleni fellépés kormányzati intézkedéseinek meghatározását.

Érték: Az említett kutatások feltárták az áldozatsegítő rendszer fejlesztési pontjait, hozzájárultak az emberkereskedelem jelenségének mélyebb megértéséhez.
\end{abstract}

Kulcsszavak: emberkereskedelem, kizsákmányolás, kutatás, áldozatsegítés

\begin{abstract}
Aim: Several forward-thinking researches have taken place in the topic of trafficking in human beings over the past two years. The review essay presents the scope of the research projects, their key features and findings, thus encouraging professionals working in this field as well as the wider audience to take a closer look at them.
\end{abstract}

Methodology: For the above purpose, three handbooks are presented below.

Findings: The research activities help to define government measures to combat human trafficking with reliable, scientific results.

Value: The researches revealed the gaps and possible improvements of the victim support system and also contributed to a deeper understanding of the phenomenon. 
Keywords: trafficking in human beings, exploitation, research, victim assistance

\section{Bevezetés}

A nemzeti stratégia rendelkezései alapján 2020-2021 között fokozódott az emberkereskedelem jelenségének tudományos kutatása. A Belügyminisztérium egy eddig jórészt feltáratlan témában, a munkacélú kizsákmányolást elszenvedő férfi áldozatok speciális szükségleteiről készíttetett kutatást. A családokért felelös tárca nélküli miniszter az ismételt áldozattá válás vizsgálatához biztosított finanszírozást, a Nemzetközi Migrációs Szervezet folyamatban lévő projektjében pedig a kizsákmányolás pszichológiai összefüggéseiről készült egy hiánypótló tanulmány. Ezek elősegítették a jelenség mélyebb megértését, illetve az ellátórendszer még meglévő hiányosságainak azonosításával előkészítették a következő évek szakpolitikai tervezését.

\section{Áldozatsegítés a férfiak körében}

Köztudott, hogy az emberkereskedelem elleni küzdelem eleinte elsősorban a nő- és leánykereskedelemre, a prostitúció áldozatainak megóvására irányult. Az azonosított áldozatok között a nők továbbra is túlnyomó többségben vannak szerte a világon és Magyarországon is. Ennek megfelelően a hazai ellátórendszer - ahogy a 2000-es években formálódott - természetes módon a gyakori esetekhez, a szexuális kizsákmányolás női áldozataihoz igazította munkamódszereit és szolgáltatásait. Ezzel párhuzamban az emberkereskedelem kutatása is féloldalas a prostitúcióban történő kizsákmányolás irányába. ${ }^{1}$ Az elmúlt években ugyanakkor elkezdett láthatóbbá válni a kényszermunka, illetve azon belül a házi rabszolgaság jelensége, s férfi áldozatok is növekvő számban jelennek meg a segítő szervezeteknél. Erre tekintettel a Belügyminisztérium 2020 nyarán 1,8 millió forintot különített el a különbözö kizsákmányolási formákat elszenvedő áldozatok eltérő ellátási igényeinek vizsgálatára. A nyílt pályázati felhívás a legszélesebb körben került közzétételre: az emberkereskedelem elleni küzdelemben érintett kormányzati szerveket tömörítő Nemzeti Koordinációs Mechanizmus, valamint az NGO kerekasztal tagjainak értesítése mellett megkerestük a témához kapcsolódni tudó egyetemi tanszékeket és doktori

1 Magyar nyelven a kevés kivétel egyike 2019-ben jelent meg az Európai Foglalkoztatási Szolgálat (EURES) magyarországi központjának támogatásával (Kun, 2019). 
iskolákat is. Tizenegy jelentkezés (önéletrajz és kutatási terv) érkezett, melyek közül a BM és két társminisztérium szakértöiből álló bíráló bizottság a SIMPACT Közhasznú Nonprofit Kft. pályázatát választotta ki.

2020. november végére a szerzők előtanulmányba foglalták az első hónapok szakirodalmi kutatását, és véglegesítették a terepmunkához használt interjúvázlatot. Második fázisban mélyinterjúk készültek az emberkereskedelem áldozatainak ellátásában jártas szakemberekkel és a munkacélú kizsákmányolás túlélőivel. A férfi áldozatokat övező látenciát ismerve különösen figyelemre méltó az áldozati interjúk 20 fős elemszáma, amely által minden korábbinál hitelesebb képet kaphatunk az áldozattá válás hátteréről.

Megjegyzendő, hogy a férfi áldozatok egyébként is nehéz elérését a koronavírus-járvány tovább rontotta. A szociális intézményekben elrendelt látogatási tilalom miatt a kutatók egyes áldozatokkal hónapokon át nem tudtak interjút készíteni; a szakértői beszélgetések során jól alkalmazható online kapcsolódás a kizsákmányolásban érintett személyek esetén nyilvánvalóan túl személytelen lett volna az élettörténetük megismeréséhez. A rekrutációs nehézségre tekintettel a záró tanulmány eredeti leadási határidejét a Belügyminisztérium négy hónappal, 2021. június végéig meghosszabbította.

2021 közepére a kutatók benyújtották a záró tanulmányt, melyből 2021 decemberére nyomtatott kiadvány született.

„Az emberkereskedelem férfi áldozatainak egyedi ellátási igényei” címü kézikönyv (Bakó, Hárs, Héra \& Berkes, 2021) öt tematikus egységből épül fel. Az első fejezet körképet ad az emberkereskedelem globális és magyarországi helyzetéről, alátámasztva a legfrissebben elérhető statisztikai adatokkal. A második fejezetben a szerzők ismertetik a nemzeti áldozatirányítási mechanizmus és az ellátórendszer működését, illetve kitekintő jelleggel egybegyüjtik a férfi áldozatok segítése terén elérhető nemzetközi jó gyakorlatokat. Az interjúk tapasztalatait a következő két fejezet dolgozza fel, majd a kutatók által megfogalmazott fejlesztési javaslatok zárják a tanulmányt.

Az első két - áttekintő, rendszerező jellegü - fejezet kiemelkedően hasznos része a más európai országok által eredményesen megvalósított, konkrét hiányosságokra reagáló projektek bemutatása, ami a hazai stratégiai tervezéshez is inspirációt jelenthet. Emellett a szerzők kísérletet tesznek három kiválasztott nyugat-európai országban (Egyesült Királyság, Franciaország, Hollandia) az áldozatoknak állandó jelleggel biztosított segítő szolgáltatások bemutatására (például jogsegély, egészségügyi ellátás, védett szálláshelyek típusai), bár itt kiütközik, hogy csak másodlagos források álltak rendelkezésre, így ezek az információk az áldozatsegítés magyarországi gyakorlatával nehezen vethetők össze. 
A szakemberekkel készült interjúk hármas szempontrendszert követtek. A beszélgetések alapján a kutatók felállították a férfi áldozatok profilját, bemutatva a munkacélú kizsákmányoláshoz vezető személyes körülményeket. Ezt követően az áldozati létben maradást, illetve a kilépést segítő tényezőket vették számba. Végezetül az interjúalanyok részletes visszajelzést adtak az áldozatsegítő rendszer fejlesztési pontjairól (áldozatok azonosítása és irányítása, pénzügyi támogatások, védett házas elhelyezés, szakmai együttmüködések, társadalmi reintegráció).

A következő fejezet eltérő részletességgel, de ugyanezen témákat dolgozza fel az áldozatok szemszögéből. Itt még aprólékosabban feltárják az emberkereskedelemmel szembeni sérülékenység egyes elemeit (családi háttér, iskolai tanulmányok, munkaerőpiaci tapasztalatok). Ezt követően az interjúalanyok felidézték az áldozattá válás folyamát - a toborzás során egybehangzóan még az ígéretek dominálnak, amikből egy idő után a kizsákmányolók egyre kevesebbet tartanak be és egyre többet követelnek, fenyegetéssel, fizikai bántalmazásokkal törik meg áldozataikat.

A szerzők élesen elkülönítik a külföldi kényszermunkában és a házkörüli rabszolgaságban („csicskáztatás”) érintett áldozatokat. Előbbi célcsoportba jellemzően fiatalabb, 20-40 év közötti férfiak tartoznak, akik a magasabb bérezés reményében, internetes hirdetésekre jelentkezve kerültek csapdahelyzetbe. A házkörüli rabszolgaság tipikus áldozatai ezzel szemben 50 év feletti férfiak, akik a hajléktalanság és tartós munkanélküliség elől szegődnek el későbbi kizsákmányolóikhoz. Ez a párba állítás a fejezet végén, az áldozatok jövőről alkotott képénél is megjelenik: a külföldi kényszermunka áldozatai többnyire rendelkeznek olyan szakmával, ami megkönnyíti a talpra állásukat, így az ellátórendszerrel csak elvétve kerülnek kapcsolatba. A házkörüli rabszolgaság csapdájába esett férfiak új életkezdési esélyei sokkal kedvezőtlenebbek: leromlott fizikai és mentális állapotuknál fogva önálló életvitelre már ritkán alkalmasak, általában csak tartós intézményi ellátás esetén óvhatók meg az ismételt áldozattá válás veszélyeitől.

A szerzők az interjúkat feldolgozó két fejezetben számos beszélgetésrészletet idéznek, amik még közelebb hozzák az áldozattá válás folyamatát és a kizsákmányoló helyzetbe került személyek reménytelenségét.

Az 5. fejezet összegzi a nemzetközi jó gyakorlatok, illetve a terepen dolgozó szakemberek és az áldozatok beszámolói alapján indokolt fejlesztési javaslatokat. Különösen hangsúlyos a kilépést követően azonnal elérhetö ügyvédi segítség és az egészségügyi ellátáshoz való hozzáférés. A szerzők a döntéshozók figyelmébe ajánlják továbbá az emberkereskedelem áldozatai részére fenntartott férőhelyek létrehozását a pszichiátriákon, azokra az esetekre, amikor 
a kimenekített áldozatok mentális állapota meghaladja a védett házak kompetenciáját. Hasonló férőhely-biztosításra van szükség idősek otthonaiban, ami egy új kimeneti csatornát nyithat a védett házakból kikerülő időskorú áldozatok számára. A nemzeti stratégia új intézkedési terve számos ponton merít a Belügyminisztérium és a SIMPACT együttmüködésében elkészült kutatásból (URL1).

\section{Az ismételt áldozattá válás elkerülése}

Az ellátórendszert érintően a családokért felelős tárca nélküli miniszter is finanszírozott egy kutatási projektet ${ }^{2} 2020-2021$ folyamán, melynek fókusza az ismételt áldozattá válás vizsgálata és az ehhez kapcsolódó szolgáltatásfejlesztés előkészítése volt. A kutatás a szexuális és munkacélú kizsákmányolást átfogóan vizsgálta; félig strukturált interjúkat készítettek 12 szexuális és négy munkacélú kizsákmányolást elszenvedő női áldozattal, illetve hat férfival, akik mindannyian munkáltatással elkövetett emberkereskedelem áldozatai voltak.

A szerzők két résztanulmányra osztották a kutatás eredményeit: külön anyag készült a szakemberekkel, illetve az áldozatokkal készült interjúk alapján. A tartalmi felépítés mindkét esetben a Belügyminisztérium megbízásából készült kutatással hasonlatos: az emberkereskedelem fö megnyilvánulási formái után bemutatják az áldozattá váló személyek szocio-ökonómiai hátterét, az áldozati létbe való bevonódás folyamatát, illetve a kilépési szándékot, segítségkérést befolyásoló tényezőket a különböző áldozati csoportokban.

Ezt követően térnek rá a szerzők a stratégiában jelzett terület, az utánkövetés, utógondozás problematikájára. Az emberkereskedelemhez kapcsolódó bármely szociológiai kutatásról elmondható, hogy az áldozatok szinte kizárólag a védett házakban dolgozó szakembereken keresztül érhetők el. Következésképpen a védett házas elhelyezést nem igénylő áldozatok sorsának alakulásáról lehet a legkevesebbet tudni.

A védett házba költözők esetén jelenleg korlátozottan nyílik lehetöség az áldozatok nyomon követésére. Hosszú távú mentorálás a reintegrációs lakhatási formák (félutas-kiléptető lakás, családok átmeneti otthona) igénybevétele mellett valósul meg. Képlékenyebb azoknak a helyzete, akik a védett házban eltöltött néhány hónap után önálló életet kezdenek, például visszatérnek a családjukba vagy munkásszállóra költöznek. Megtartó erő lehet a védett házak

2 A kutatás elvégzésére a CSTNM háttérintézménye, a Családbarát Magyarország Központ kapott megbízást az „Emberkereskedelem 2020” című projekt keretében. A kutatócsapat vezetője Mészáros Zoltán, szerzőtársai Ercsey-Orbán Melánia, Héra Gábor és Nagy Beáta Magda voltak. 
szakembereivel kialakult személyes kapcsolat, az életkörülmények hirtelen megváltozása, visszaesés esetén az áldozatok számíthatnak a szociális munkások újbóli segítségére. Ehhez azonban maguknak kell jelentkezni (telefonon, Facebookon), a módszeres utánkövetés feltételei (humán erőforrás, nyilvántartó rendszer, protokoll) összességében nem biztosítottak.

A kutatás a család- és gyermekjóléti szolgálat szerepét is igyekezett körüljárni. A védett ház elhagyása után rendszerint megtörténik az esetátadás, ám a szerzők felhívják a figyelmet, hogy nem szerencsés kizárólagosan a családsegítőkre hárítani az utánkövetéssel járó feladatokat.

A kutatók megállapításai alapján a nemzeti stratégia új intézkedési terve kilátásba helyezte az utánkövetéshez szükséges informatikai rendszer, illetve ehhez kapcsolódóan a védett házakban további álláshelyek kialakítását.

\section{Az áldozattá válás lélektana}

A Nemzetközi Migrációs Szervezet 2020-2022 között valósítja meg a „Ne hagyd, ne tedd! - emberkereskedelem elleni kampány" címü európai uniós projektet, melynek része volt „Az emberkereskedelem pszichológiai mozgatórugói” címü tanulmány megírása (Sebestyén, 2020). Ehhez a szerző, Sebestyén Árpád feldolgozta a rendelkezésre álló nemzetközi szakirodalmat, merített a szakpszichológusként szerzett tapasztalataiból, és nyolc áldozattal vett fel félig strukturált interjúkat.

A kézikönyv bevezető része kontextusba helyezi az emberkereskedelmet, bemutatja az áldozatok jellemző útját a kizsákmányolásig. Ezek a megállapítások már ismerősek lehetnek az előzőkben ismertetett két kutatásból, jelentős többlet viszont, hogy Sebestyén az áldozatok bevonódása, elkövetővel való azonosulása, tehetetlensége kapcsán a kizsákmányolást összeköti a modern pszichológia elméleti alapvetéseivel, melyre egyetlen magyar nyelvü kiadvány sem tett kísérletet korábban.

Ehhez kapcsolódóan részletesen jellemzi a traumákkal való szembenézés, a lelki gyógyulás lépcsőzetességét, ami minden szociális szférában dolgozó szakember számára támpontot adhat az első segítő beszélgetéshez, krízisintervencióhoz, és az áldozat hosszabb távú támogatásához. Sebestyén hangsúlyozza, hogy társas támaszok nélkül szinte lehetetlen tartósan kilábalni, így a reintegráció tervezésekor a materiális szempontok mellett (például szakmaszerzés, lakhatás megteremtése) különösen fontos a családi, baráti kapcsolatok helyreállítása, vagy ezeknek a hiányában az áldozatok becsatornázása egyéb, megtartó erővel bíró közösségekbe (sorstársak, vallási gyülekezet stb.). 
Az áldozatok lélektani megéléseit bár közvetlenül az emberkereskedelem jelenségéhez kötődően tárgyalja, nagyrészt kapcsolati erőszak vagy szexuális abúzus esetén is megállja a helyét. Az áldozati lét stádiumainak, az alávetettségben élő emberek reakcióinak közérthető ismertetésével a tanulmány tágabb értelemben az egész társadalomhoz szól, és küzdeni próbál az áldozatokat okoló, sztereotip vélekedések ellen.

A szerző a kiadvány végén új indikátorokkal egészítette ki az áldozatok azonosításához használt adatlapot, ami a jogszabály módosításához is fontos elméleti háttér volt.

\section{További publikációk az emberkereskedelem témakörében}

Az elmúlt években az emberkereskedelem jelenségét és a kapcsolódó büncselekményeket legaktívabban Windt Szandra, az Országos Kriminológiai Intézet kutatója vizsgálta, akinek számos publikációja jelent meg a Legfőbb Ügyészség szakmai lapjaiban, tanulmánykötetekben és nemzetközi folyóiratokban (URL2). Elsők között dolgozta fel az emberkereskedelem, a kényszermunka és a gyermekprostitúció kihasználása büntetteihez kapcsolódó rendőrségi, ügyészségi ügyiratokat, miközben a gyermekvédelem és a szociális ellátórendszer irányába is élö kapcsolatot ápol. Ennek köszönhetően Windt kutatásaiban a kriminológiai és szociológiai szempontok egyszerre érvényesülnek. Az elmúlt évek kutatási eredményeit a 2021 végén megjelent kötetében összegzi (Windt, 2021). A tárgyidőszakban emellett több leíró jellegü, szintetizáló anyag született (De Coll \& Tatár, 2020; Belügyminisztérium, 2021), melyekre külön nem térünk ki. ${ }^{3}$ Rögzíthetjük ugyanakkor, hogy a kutatómunka ezen a területen nem l'art pour l'art tevékenység - célja és értelme, hogy az emberkereskedelem elleni küzdelmet érintő kormányzati intézkedések megbízható eredményeken alapuljanak. A nemzeti stratégia új intézkedési terve alapján a Belügyminisztérium a következő időszakban tanulmányt fog készíttetni a prostitúció szabályozási modelljeiről, ami a jogalkotó számára fontos háttéranyag lehet a jelenlegi szabályozás felülvizsgálatához. Jelentős előrelépést remélhetünk továbbá a Pécsi Tudományegyetem emberkereskedelem elleni kutatóközpontjának köszönhetően, amely 2022-ben áll fel a holland állam támogatásával.

3 Az emberkereskedelem elleni küzdelem kormányzati honlapjának Szakirodalom menüpontjában valamennyi friss szakmai anyag elérhető elektronikus formában. 


\section{Felhasznált irodalom}

Bakó Cs., Hárs M., Héra G. \& Berkes M. (Szerk.) (2021). Az emberkereskedelem férfi áldozatainak egyedi ellátási igényei. Belügyminisztérium.

Belügyminisztérium (2021). Tansegédlet a szociális munkások képzését végzö egyetemi tanszékek számára.

De Coll Á. \& Tatár E. (2020). Az emberkereskedelem jelenlegi helyzete Magyarországon. Igazságügyi Minisztérium-Baptista Szeretetszolgálat.

Kun Zs. (Szerk.) (2019). A munkacélú kizsákmányolás megelözésének és az áldozatok segitésének lehetőségei. EURES Magyarország.

Sebestyén Á. (2020). Az emberkereskedelem pszichológiai mozgatórugói. Traumaközpont Közhasznú Nonprofit Kft. https://emberkereskedelem.kormany.hu/szakirodalom

Windt Sz. (2021). A láthatatlan emberek. Az emberkereskedelem jelensége Magyarországon. Országos Kriminológiai Intézet.

\section{A cikkben szereplő online hivatkozások}

URL1: Szakirodalmi gyüjtemény az emberkereskedelem elleni küzdelem kormányzati honlapján. https://emberkereskedelem.kormany.hu/szakirodalom

URL2: Windt Szandra adatlapja az Országos Kriminológiai Intézet weboldalán. https:/www.okri.hu/index.php/2-uncategorised/103-windt-szandra

\section{A cikk APA szabály szerinti hivatkozása}

Berkes M. (2022). Kutatásokkal az emberkereskedelem ellen. Belügyi Szemle, 70(2), 363-370. https://doi.org/10.38146/BSZ.2022.2.8 